\title{
Pengaruh Tingkat Kurs Rupiah, Harga Emas dan Harga Minyak terhadap Indeks LQ 45 Periode Maret 2013 - Juni 2016
}

\author{
Muhammad Ikhwan Nugraha \\ Sekolah Tinggi Ilmu Manajemen Indonesia (STIMI) Banjarmasin \\ Email: mikhwannugraha@yahoo.co.id
}

\begin{abstract}
This research aimed to analyze the effects of some macroeconomic variables for the movement of $L Q 45$ Index. Those macroeconomic variables used among other things were rupiah exchange rate, gold price and oil price.

The population of this research was LQ 45 Index in Indonesia Stock Exchange (BEI) from March 2013 to June 2016 and the independent variables in the same time period. The total samples, the same as the population, were 40 monthly data which were determined through a census method. The data were obtained from Indonesian Stock Exchange and other reputable websites. The data analysis was performed with the classical assumption and hypothesis testing by multiple regression.

The results of this study showed that rupiah exchange rate and oil price had a significant effect towards $L Q 45$ Index, while gold price did not have a signifiant effect towards $L Q 45$ Index.
\end{abstract}

Keywords : Rupiah Exchange Rate, Gold Price, Oil Price and LQ 45 Index

Abstrak

Penelitian ini bertujuan untuk menganalisis pengaruh dari beberapa variabel makroekonomi terhadap pergerakan Indeks LQ 45. Variabel-variabel makroekonomi yang digunakan antara lain kurs rupiah, harga emas dan harga minyak.

Populasi dari penelitian ini adalah Indeks LQ 45 di Bursa Efek Indonesia (BEI) pada bulan Maret 2013 Juni 2016 dan variabel-variabel independennya pada waktu yang sama. Total sampel, sama dengan populasi, adalah 40 data bulanan yang ditentukan dengan metode sensus. Data diambil dari situs resmi Bursa Efek Indonesia dan situs lainnya dengan reputasi baik. Analisis data dilakukan dengan uji asumsi klasik dan hipotesis melalui regresi berganda.

Hasil penelitian menunjukkan bahwa kurs rupiah dan harga minyak memiliki pengaruh yang signifikan terhadap Indeks LQ 45, sedangkan harga emas tidak memiliki pengaruh yang signfikan terhadap Indeks LQ 45.

Kata Kunci : Kurs Rupiah, Harga Emas, Harga Minyak dan Indeks LQ 45

\section{PENDAHULUAN}

Penelitian terhadap pasar modal merupakan hal yang menarik dan penting untuk dilakukan. Hal ini karena pasar modal merupakan salah satu perameter baik atau tidaknya iklim investasi dan tingkat kesejahteraan masyarakat. Berbeda dengan IHSG yang merupakan indeks secara keseluruhan, Indeks LQ 45 adalah indeks penting yang merangkum 45 saham paling liquid dari Bursa Efek Indonesia. Indeks ini meliputi setidaknya 70 persen dari kapitalisasi pasar saham dan nilai nilai transaksi di BEI. Indeks LQ 45, yang dimulai pada bulan Februari 1997, memakai kurs rupiah dan dipublikasikan selama waktu perdagangan di BEI. Indeks ini diperbarui tiap 6 bulan sekali, yaitu pada awal bulan Februari dan Agustus.
Lima kapitalisasi terbesar berdasarkan daftar perusahaan yang termasuk dalam Indeks LQ 45 periode Agustus 2016 - Januari 2017 dipegang oleh Hanjaya Mandala Sampoerna Tbk dengan nilai kapital lebih dari 472 triliun rupiah, urutan kedua ditempati emiten Telekomunikasi Indonesia (Persero) Tbk dengan nilai modal 428 triliun rupiah, kemudian Bank Central Asia Tbk berada di urutan ketiga saham terbesar dengan nilai modal 350 triliun rupiah, lalu Unilever Indonesia Tbk dengan nilai kapital 342 triliun rupiah dan Astra Internasional Tbk. dengan nilai kapital 301 triliun rupiah.

$\begin{array}{cccc} & \text { Mengacu pada jumlah kapital Indeks LQ } 45 \\ \text { secara } & \text { keseluruhan } & \text { sebesar }\end{array}$ 3.855.440.952.803.170, maka Hanjaya Mandala Sampoerna Tbk yang merupakan sektor Consumer Goods, secara nilai kapital memegang persentase 
sebesar 12,24 persen dari indeks LQ45. Emiten Telekomunikasi Indonesia (Persero) Tbk dari sektor Infrastruktur secara nilai kapital memiliki persentase sebesar 11,11 persen dari indeks LQ45. Emiten Bank Central Asia Tbk yang merupakan sektor Keuangan memiliki persentase sebesar 9,08 persen. Emiten Unilever Indonesia Tbk dari sektor Consumer Goods secara nilai kapital memiliki persentase sebesar 8,89 persen. Emiten Astra Internasional Tbk yang merupakan sektor Industri beragam secara nilai kapital memiliki persentase sebesar 7,82 persen.

Pembagian Indeks LQ 45 persektor ini penting untuk mengetahui variabel apa saja yang kiranya berpengaruh, misal untuk sektor industri dan Consumer Goods yang bahan bakunya impor, maka perubahan kurs akan berdampak signifikan. Lain halnya dengan saham properti, kenaikan harga emas tentu akan berpengaruh. Begitu pula dengan saham sektor industri yang menggunakan banyak bahan bakar minyak, maka penurunan harga minyak tentu mengakibatkan biaya produksi ikut turun, yang pada gilirannya mempengaruhi harga saham.

Penggunaan proxy sangat beragam dalam penelitian nilai Indeks LQ 45, hal tersebut sangat terlihat dari penentuan parameter pengukuran, variabel dependen dan variabel independen yang cukup beragam dari masing masing penelitian, didasari atas teori yang menjadi referensi masingmasing peneliti. Lebih jauh, studi ini meneliti hubungan dan besarnya pengaruh antara variabelvariabel kurs rupiah, harga emas dan harga minyak terhadap pergerakan Indeks LQ 45.

Penelitian ini menggunakan data saat harga minyak dunia mengalami kejatuhan sampai tinggal sepertiganya, dimulai dari pertengahan tahun 2014, dan kurs rupiah yang pada awal tahun 2013 berada pada rentang 10000 rupiah per dolar AS menjadi 13000 rupiah per dolar AS pada tahun 2016. Proxy pergerakan harga emas bunga juga menjadi hal yang menarik untuk diteliti. Penulis tertarik untuk melakukan penelitian lebih dalam mengenai "Pengaruh Kurs Rupiah, Harga Emas dan Harga Minyak terhadap Indeks LQ 45 Periode Maret 2013 - Juni 2016"

\section{KAJIAN LITERATUR}

\section{Indeks LQ 45}

Menurut Hartono (2010:106) pasar modal di Indonesia masih tergolong pasar modal yang transaksinya tipis (thin market), yaitu pasar modal yang sebagian besar sekuritasnya kurang aktif diperdagangkan. IHSG yang mencakup semua saham yang tercatat (yang sebagian besar kurang aktif diperdagangkan) dianggap kurang tepat sebagai indikator kegiatan pasar modal. Oleh karena itu pada tanggal 24 Februari 1997 dikenalkan alternatif indeks yang lain, yaitu Indeks Liquid 45.

Dasar untuk perhitungan Indeks LQ 45 adalah penjumlahan atau agregat nilai pasar dari semua saham yang terdaftar di BEI pada tanggal 13 Juli 1994. Tanggal tersebut disebut sebagai base day dengan nilai index 100. Agregat nilai pasar adalah total penjumlahan semua saham terdaftar (tidak termasuk saham-saham dari perusahaan yang sedang melakukan restrukturisasi) dengan setiap harganya di BEI pada hari itu.

Formula yang dipakai adalah:

\section{LQ 45 = Nilai Pasar / Nilai Dasar x 100.}

\section{Tingkat Suku Bunga}

Menurut Tandelilin (2001:343) tingkat bunga yang terlalu tinggi akan mempengaruhi nilai sekarang (present value) aliran kas perusahaan sehingga kesempatan-kesempatan investasi yang ada tidak akan menarik lagi. Tingkat bunga yang tinggi juga akan meningkatkan biaya modal yang harus ditanggung perusahaan. Di samping itu tingkat bunga yang tinggi juga akan menyebabkan return yang disyaratkan investor dari suatu investasi akan meningkat.

Tingkat suku bunga yang dimaksud dalam penelitian ini adalah suku bunga BI atau BI rate. Apabila inflasi di atas target, BI biasanya akan menaikkan BI Rate dan ketika inflasi di bawah target BI Rate biasanya akan diturunkan. BI rate ditetapkan sebulan sekali melalui Rapat Dewan Gubernur (RDG) dengan perubahan kelipatan dua puluh lima basis poin (bps). Ketika terjadi hal-hal di luar perkiraan, perubahan dilakukan seminggu sekali, begitu juga perubahan bisa saja melebihi 25 bps, namun tetap dengan kelipatan 25 bps. (www.bi.go.id)

\section{Kurs Rupiah}

Menurut Tandelilin (2001:344) menguatnya nilai tukar rupiah (kurs) terhadap nilai mata uang negara lain merupakan tanda positif kepada perekonomian yang mengalami penurunan nilai mata uang atau inflasi. Penjelasannya adalah menguatnya kurs rupiah terhadap mata uang asing akan menurunkan biaya impor bahan baku untuk produksi, dan akan menurunkan tingkat suku bunga yang berlaku. Angka yang digunakan adalah kurs tengah mata uang dolar AS terhadap rupiah yang ditetapkan oleh Bank Indonesia dengan satuan nilai $\mathrm{Rp} / 1$. 
Harga Emas

Harga emas yang dipakai adalah London Gold Fixing. Sistem ini menentukan harga emas dari persetujuan anggota dari London Gold Market Fixing Ltd. Anggotanya sekarang adalah Barclays, Bank of China, Bank of Communications, Goldman Sachs, HSBC Bank USA, JPMorgan Chase, Morgan Stanley, Société Générale, Standard Chartered, ScotiaMocatta (Scotiabank), Toronto-Dominion Bank dan UBS. Harga emas dikeluarkan berdenominasi dolar AS, poundsterling Inggris dan Euro tiap hari pada pukul 10.30 dan 15.00 waktu London.

\section{Harga Minyak}

Terdapat beberapa harga minyak yang menjadi referensi harga untuk para penjual dan pembeli minyak, seperti West Texas Intermediate (WTI), Brent ICE, Dubai Crude, harga referensi dari OPEC dan lain-lain. Pembagian tersebut berdasarkan beberapa kriteria seperti lokasi dan kualitasnya. Pada penelitian ini harga minyak yang dipakai adalah harga spot dari WTI yang diperdagangkan di Cushing, Oklahoma, Amerika Serikat dengan satuan dolar AS per barrel.

\section{Hipotesis}

$\mathrm{H}_{1}$ : Tingkat suku bunga berpengaruh negatif terhadap Indeks LQ 45 periode Maret 2013 - Juni 2016.

$\mathrm{H}_{2}$ : Kurs rupiah berpengaruh positif terhadap Indeks LQ 45 periode Maret 2013 - Juni 2016.

$\mathrm{H}_{3}$ : Harga emas berpengaruh negatif terhadap Indeks LQ 45 periode Maret 2013 - Juni 2016.

$\mathrm{H}_{4}$ : Harga minyak berpengaruh negatif terhadap Indeks LQ 45 periode Maret 2013 - Juni 2016.

\section{METODE PENELITIAN}

Penelitian ini menggunakan metode kuantitatif untuk perolehan data. Di metode kuantitatif, populasi adalah jumlah semua hal atau elemen yang akan diteliti, sedangkan sampel adalah bagian dari populasi, yaitu jumlah lebih kecil yang diambil dari populasi (Buglear, 2005:110). Populasi dalam penelitian ini adalah sama dengan sampel yang digunakan, yaitu Indeks LQ 45 bulanan dari Maret 2013 sampai dengan Juni 2016, yang berjumlah sebanyak 40 data indeks.

\section{Teknik Pengumpulan Data}

Teknik pengumupulan data yang digunakan dalam penelitian ini adalah teknik pengumpulan dokumentasi data arsip (archival) yang berupa data sekunder. Menurut Buglear (2005:111), data sekunder adalah data yang telah dikumpulkan oleh

Tabel 2

Hasil Uji t

\begin{tabular}{|c|c|c|c|c|c|c|}
\hline \multirow[b]{2}{*}{ Model } & & \multicolumn{2}{|c|}{$\begin{array}{c}\text { Unstandardized } \\
\text { Coefficients }\end{array}$} & \multirow{2}{*}{$\begin{array}{c}\begin{array}{c}\text { Standardized } \\
\text { Coefficients }\end{array} \\
\text { Beta } \\
\end{array}$} & \multirow[b]{2}{*}{$\mathrm{t}$} & \multirow[b]{2}{*}{ Sig. } \\
\hline & & $\mathrm{B}$ & Std. Error & & & \\
\hline \multirow[t]{5}{*}{1} & (Constant) & 489.142 & 111.911 & & 4.371 & 0 \\
\hline & Lag_X1 & -20.027 & 33.952 & -0.092 & -0.59 & 0.56 \\
\hline & Lag_X2 & -0.049 & 0.014 & -0.586 & -3.396 & 0.002 \\
\hline & Lag_X3 & 0.016 & 0.121 & 0.022 & 0.13 & 0.897 \\
\hline & Lag_X4 & -2.232 & 0.682 & -0.542 & -3.272 & 0.003 \\
\hline
\end{tabular}

a. Dependent Variable: Lag_Y

orang lain. Data yang digunakan adalah pada hari terakhir kerja tiap bulan dari Maret 2013 sampai Juni 2016, dengan data $B I$ rate adalah data pada hari terakhir tiap bulan yang diambil dari situs Bank Indonesia www.bi.go.id, data kurs rupiah diambil dari siturs finance.yahoo.com dengan satuan nilai $\mathrm{Rp} / 1$, data harga emas dari situs fred.stlouisfed.org dengan satuan nilai dolar AS per Troy Ounce, data harga minyak dari situs fred.stlouisfed.org dengan satuan nilai dolar AS per barrel dan Indeks LQ 45 dari situs finance.yahoo.com.

\section{Teknik Analisa Data}

Teknik analisis yang digunakan pada penelitian ini adalah menggunakan analisis data regresi linier berganda termasuk dengan uji koefisien determinasi, koefisien korelasi dan uji secara parsial menggunakan uji t serta uji f dengan bantuan program SPSS (Statistic Product \& Services Solution) versi 25.

\section{HASIL PENELITIAN DAN PEMBAHASAN}

\section{Koefisien Determinasi $\left(\mathbf{R}^{\mathbf{2}}\right)$}

Koefisien determinasi merupakan besarnya kontribusi variabel bebas terhadap variabel tergantungnya. Semakin tinggi koefisien determinasi, semakin tinggi kemampuan variabel bebas dalam menjelaskan variasi perubahan pada variabel tergantungnya (Suliyanto, 2011:55).

\section{Tabel 1}

Hasil Uji Koefisien Determinasi $\left(\mathbf{R}^{2}\right)$

\begin{tabular}{|c|c|c|c|c|c|}
\hline Model & $\mathrm{R}$ & $\mathrm{R}$ square & $\begin{array}{l}\text { Adjusted } \\
\text { R Square }\end{array}$ & $\begin{array}{l}\text { Std. Error } \\
\text { of the } \\
\text { Estimate }\end{array}$ & $\begin{array}{l}\text { Durbin- } \\
\text { Watson }\end{array}$ \\
\hline 1 & $0.628^{\mathrm{a}}$ & 0.394 & 0.316 & 31.58288 & 1.437 \\
\hline
\end{tabular}


Tabel 3

Hasil Uji F

\begin{tabular}{lllllll}
\hline \hline Model & & Sum of & & & & \\
& & Sean & & \\
& & Squares & df & Square & F & Sig. \\
\hline \hline \multirow{2}{*}{1} & Regression & 20128.216 & 4 & 5032.054 & 5.045 & $0.003^{\text {a }}$ \\
& Residual & 30921.831 & 31 & 997.478 & & \\
& Total & 51050.047 & 35 & & & \\
\hline \hline
\end{tabular}

a. Predictors: (Constant), Lag_X1, Lag_X2,LLa_X3, Lag_X4

b. Dependent Variable: Lag_Y

Nilai koefisien adjusted $\mathrm{R}^{2}$ berdasarkan tabel 1 adalah sebesar 0.316. Hal ini berarti variabilitas variabel dependen yang dapat dijelaskan oleh variabel independen adalah sebesar $31,6 \%$, dengan kata lain 31,6\% Indeks LQ 45 dipengaruhi variabel tingkat suku bunga, kurs rupiah, harga emas dan harga minyak. Variabel lain yang tidak diteliti dalam penelitian ini mempengaruhi Indeks LQ 45 sebesar 68,4\%.

Uji Signifikan Secara Parsial (Uji t)

Sumber: Hasil SPSS, data diolah (2017)

Model regresi berdasarkan table 2 adalah:

Lag_Indeks LQ $45=489,142-20,027$

Lag_Tingkat suku bunga - $\mathbf{0 , 0 4 9}$ lag_Kurs rupiah + 0,016 Lag_Harga emas - 2,232 Lag_Harga minyak

Pada tingkat signifikansi 0,05 diperoleh nilai signifikansi $\mathrm{t}$ untuk variabel tingkat suku bunga sebesar 0,56 (signifikansi t >0,05). Dengan demikian terbukti bahwa variabel tingkat suku bunga BI Rate tidak berpengaruh terhadap Indeks LQ 45.

Pada tingkat signifikansi 0,05 diperoleh nilai signifikansi $t$ untuk variabel kurs rupiah sebesar 0,002 (signifikansi $\mathrm{t} \leq 0,05$ ). Dengan demikian terbukti bahwa variabel kurs rupiah berpengaruh terhadap indeks LQ 45. Koefisien variabel kurs rupiah sebesar -0,049, dipandang dari kurs rupiah artinya adalah bahwa semakin rupiah menguat (jumlah rupiah untuk mendapatkan 1 dolar AS mengecil) maka akan menaikkan Indeks LQ 45.

Pada tingkat signifikansi 0,05 diperoleh nilai signifikansi $\mathrm{t}$ untuk variabel harga emas sebesar 0,897 (signifikansi $t>0,05$ ). Dengan demikian terbukti bahwa variabel harga emas tidak berpengaruh terhadap indeks LQ 45.

Pada tingkat signifikansi 0,05 diperoleh nilai signifikansi t untuk variabel harga minyak sebesar 0,003 (signifikansi $\mathrm{t} \leq 0,05$ ). Dengan demikian terbukti bahwa variabel harga minyak berpengaruh terhadap indeks LQ 45. Koefisien variabel harga minyak sebesar $-2,232$ berarti bahwa semakin tinggi harga minyak maka akan menurunkan Indeks LQ 45, artinya harga minyak berbanding terbalik dengan Indeks LQ 45.

\section{Uji Signifikan Secara Simultan (Uji F)}

Sumber: Hasil SPSS, data diolah (2017)

Berdasarkan hasil uji $\mathrm{F}$ pada table 3 diperoleh hasil nilai $\mathrm{F}$ sebesar 5,045 dengan taraf signifikansi lebih kecil dari $\alpha=5 \%$, maka dapat dikatakan bahwa variable tingkat suku bunga, kurs rupiah, harga emas dan harga minyak secara simultan berpengaruh signifikan terhadap variable Indeks LQ 45.

\section{PENUTUP}

\section{Kesimpulan}

1. Hasil pengujian menunjukkan bahwa secara parsial variabel tingkat suku bunga tidak berpengaruh signifikan terhadap indeks LQ 45, kurs rupiah berpengaruh signifikan dengan arah positif terhadap indeks LQ 45, harga emas tidak berpengaruh signifikan terhadap indeks LQ 45 dan harga minyak berpengaruh signifikan dengan arah negatif terhadap indeks LQ 45.

2. Koefisien determinasi, nilai Adjusted R2 pada persamaan regresi dalam penelitian ini adalah 0,316 dan dapat diartikan bahwa 31,6\% variasi indeks LQ 45 dapat dijelaskan oleh variasi dari variabel-variabel independen yang digunakan dalam penelitian ini.

\section{DAFTAR PUSTAKA}

Al Hayky, Ahmed., Nizam Naim. 2015. The Relationship between Oil Price and Stock Market Index: An Empirical Study from Kuwait. Kingdom of Bahrain: Ahlia University.

Buglear, John. 2005. Quantitative Methods for Business. Amsterdam: Elsevier ButterworthHeinemann.

Ferdinand, Augusty. 2014. Metode Penelitian Manajemen. Semarang: Badan Penerbit Universitas Diponegoro.

Ghozali, Imam. 2005. Aplikasi Analisis Multivariate dengan Program SPSS. Semarang: Badan Penerbit Universitas Diponegoro. 
Hartono, Jogiyanto. 2010. Teori Portofolio dan Analisis Investasi. Edisi ketujuh. Yogyakarta: Badan Penerbit Fakultas Ekonomi.

Jaffe, J. 1989. Gold and Gold Stocks as Investment for Institutional Portfolios. Financial Analysts Journal. CFA Institute.

Jaffe, J. 1989. Gold and Gold Stocks as Investment for Institutional Portfolios. Financail Analysts Journal. CFA Institute.

Rusbariand, dkk. 2012. Analisis Pengaruh Tingkat Inflasi, Harga Minyak Dunia, Harga Emas Dunia dan Kurs Rupiah Terhadap Pergerakan Jakarta Islamic Index di Bursa Efek Indonesia. Forum Bisnis \& Keuangan I hal. 724-740.

Tandelilin, Eduardus. 2001. Analisis Investasi dan Manajemen Portofolio. Yogyakarta: Badan Penerbit Fakultas Ekonomi.

Witjaksono, A. A. 2010. Analisis pengaruh tingkat suku bunga SBI, Harga Minyak Dunia, Harga Emas Dunia, Kurs Rupiah, Indeks Nikkei 225 dan Indeks Dow Jones terhadap IHSG. Tesis. Program Studi Magister Manajemen. Universitas Diponegoro. Semarang.

fred.stlouisfed.org (03 Maret 2017)

finance.yahoo.com (04 April 2017)

www.bi.go.id (03 Maret 2017)

www.idx.co.id (03 Maret 2017)

www.google.co.id (12 Maret 2017)

\section{Profil Penulis}

1. Muhammad Ikhwan Nugraha, S.T., M.M., Keilmuan Manajemen, Sekolah Tinggi Ilmu Manajemen Indonesia (STIMI) Banjarmasin, Jl. Kuripan No. 26 Banjarmasin - 70123 Email: mikhwannugraha@yahoo.co.id 